\title{
The Role of Uncertainty Avoidance and Situational Abnormality in Satisfaction-Trust- Loyalty Link
}

\author{
Mark Ojeme, Erdem Kırkbeşoğlu, Betül Doğan
}

\begin{abstract}
Purpose - The relational link between satisfaction-trust-loyalty is rather complex and dynamic. This paper examines the effect of situational abnormality (SA) and uncertainty avoidance (UA) variables as moderators to trust and loyalty outcomes in the Turkish Automobile Industry. The research proposed a theoretical model with SA and UA interaction effects on the proposed loyalty relational link.
\end{abstract}

Design/methodology/approach - Existing instruments were employed to sample 250 customers of an insurance company in Turkey, 200 returned questionnaires were used. Two-stage data analysis method was employed. Confirmatory Factor Analysis was used to establish the research constructs' validity and model goodness of fit, while Structural Equation Modelling was employed to test the proposed model hypotheses.

Findings - In the pivotal model, the result showed that UA was not significant, but SA mitigated strongly on relational outcomes when compared to the rival model, which had stronger and positive customer loyalty intention. The findings reveals that SA led to a negative customer's loyalty disposition towards their insurance service provider in Turkey.

\section{Research limitations/implications -}

The research data was homogenously analysed without conducting analysis on demographics such as relationship length, profession or family profile. There is value in extending the current research by considering demographic effects on the research model.

Originality/value - the research developed a relational model that embeds contextual factors in the Turkey insurance sector. The research shows that SA had a strong influence on the relationship dynamics within the context. The paper proves the value of SA importance, especially when the environment is dynamic and risky.

Keywords: Insurance, Loyalty, Trust, Uncertainty Avoidance and Situational Abnormality. 


\section{Introduction}

Many studies agrees on the important role of satisfaction, trust and loyalty in the development of sustained long-term relationship both in the Business to Business (B2B) (Morgan and Hunt, 1994; Doney and Canon, 1997; Doney, Barry, \& Abratt, 2007 and Business to Customers (B2C) relational domains (Moorman et al. 1992, 1993; Sekhon et la., 2013; Kharouf, Lund, and Sekhon, 2014). Whilst there is the general concession of this relational model link, developing sustained relationship is rather complex and dynamic (Johnson and Auh, 1998), and there are considerably diverse and mix of factors that have been developed and integrated to examine the interaction effect and strength of the linear relationship between satisfaction, trust and loyalty.

The literature shows that studies have investigated the effect of switching cost (Pick and Eisend, 2016; Nagengast et al., 2014), experience (Dagger and O’Brien, 2010), commitment (Bansal, Irving and Taylor, 2004; Fullerton, 2011; Ojeme, 2018), complaint handling (Homburg, Fürst and Koschate, 2010), trust and distrust (Cho, 2006), service quality (Zeitham, Berry and Parasuraman; 1996; Setó-Pamies, 2012), and perceived value (Meyer-Waarden, 2013; Pura, 2005). Other studies have performed time series analysis integrating the moderating effect of relationship length (Ojeme, 2017), and longitudinal relational studies (Kim, Ferrin, and Rao, 2009). Furthermore, academics have examined the effect of contextual service setting such as luxury product markets (Chiou and Droge, 2006); service oriented business (Jain, Malhotra and Guan, 2012), and non-for -profit organisations (Naskrent and Siebelt, 2011). The pivotal reason why academics and practitioners are continually keen on the strength of customer loyalty is based on the overarching argument of cost efficiency and business profitability of retained customers (Chiou and Droge, 2006; Reichheld and Sasser,1990).

Notwithstanding the importance of satisfaction - trust - loyalty in developing long-term relationship, the input of situational factors in this relational model link remains scanty and underresearched (McLeary and Cruise, 2015). Situational normality plays a significant role in the development of trust. The seminal work of McKnight and Chervany (2002: 41-42) posits from a sociological stance points that "behaviours are situationally constructed. In this paradigm, action is not determined by factors within the person but by the environment or situation". Despite the need for studies to consider the situational normality on relationship development, in particular 
trust (McLeary and Cruise, 2015; Mcknight and Chervany, 2002), many studies still consider trust from a more universal and generalisable setting (Zaheer and Zaheer, 2006), ignoring the critical need to consider the contextual settings of trust development (McLeary and Cruise, 2015).

The situational basis of relationship development and how it defines relational variable of trust remains problematic in the literature (McKnight and Chervany, 2002). Furthermore, relational variable such as trust over the past 50 years remains difficult to define, despite been prevalent as a pivotal construct for relationship sustenance (Doney and Cannon, 1997; Nicholson et al, 2001; Mouzas et al., 2007; Akrout, 2015; Robson, et al., 2016 ). The purpose of this research is not to delve into the debate of trust definition and conceptualisation, but to examine the effect that shape and influence the development of trust and associated relational variables embedded in a situational domain.

This study considers uncertainty avoidance (UA) and situational abnormality (SA) as the two fundamental contextual variables in the investigation of the relational model of satisfaction - trust - loyalty. The rationale for selecting UA and SA to underpin the relational model stems from the consideration that relationships, especially trust is influenced by the prevailing environmental factors (McLeary and Cruise, 2015; Mcknight and Chervany, 2002). UA effect on relationship building is an under research area in service marketing literature, thus there is the need to examine the role this prominent Hofstede's cultural factor plays on customer relationship. The research proposition aims to develop a theoretical relational model that is underpinned by UA and SA. The paper goal is to investigate how UA and SA moderates on relationship strengths in the insurance service sector. The next section presents a literature review and a research model with hypothetical propositions. Subsequent section covers the methodology followed to access data and empirically test the research model. Consequently, the paper will analyse the results, discuss the findings and finish with a conclusion and recommendation.

\section{Literature Review}

\section{Uncertainty Avoidance (UA)}

UA is a theoretical concept underpinned by customers' level of anxiety towards a vague, erratic, and indeterminate future (Hofstede, 2001, Hofstede et al. 2010; Bellis et al. 2015). The UA concept is defined as "extent to which the members of a culture feel threatened by ambiguous or unknown 
situations" (Hofstede et al. 2010, p. 191). Similarly, De Bellis et al (2015, p.311) defined UA as the "degree to which a country's residents deal with uncertainty regarding a future environment". A key emerging concept of UA connotes "uncertainty" as people feel threatened due to an ambiguous situational context. This study choice of UA cultural dimension is based on the level of ambiguity and uncertainty that surrounds the insurance industry and the nature of services provided by this particular industry. Predominantly, services is classified as intangible, heterogeneous, inseparable and perishable (IHIP) (Edgett and Parkinson, 1993; Zeithaml et al., 1985). For instance, in the insurance service provision, no two customers will probably receive the same insurance policy as this is based on individual-to-individual circumstances, which in most cases tend to differ. This is referred to as environmental heterogeneity (Coelho and Easingwood, 2005). A situation where there is a high degree of perceived dissimilarity amongst the prospective insurance customers.

The literature appears to have interwoven and use inter-changeably uncertainty avoidance and risk avoidance as the same concept (Hofstede et al, 2011), Importantly, Hofstede et al $(2011,197)$ emphasised that "UA should not be confused with risk avoidance". In differentiating the two concepts, Hofstede underpinned risk to be associated with a specific event whereas UA relates to diffused feelings and not a specific object (Storrud-Barnes and Jessup, 2010). Toma, Chitita and Sarpe (2012) defines risk as the circumstances in which probabilities targets are identifiable for possible outcomes. Instead, uncertainty refers to situations or events where the customer has insufficient information to identify objective probabilities. Furthermore, risk is associated with probability that a particular event will occur which may engender fear. On the other hand, UA does not connote a probability attached to it, but rather a situation in which anything can happen which is more associated with anxiety (Hofstede et al, 2011). Thus, when risk avoidance is concerned with a specific object it relates more to fear and sometimes a source of routine, conversely, in UA there is no specific object focus and the emphases is usually on the feeling of anxiety.

UA relates to how society perceives ambiguity and react unusual situations (Hofstede, Hofstede and Minkov, 2010). The theoretical illustration of UA underpins that society that are high in UA would usually take steps to reduce the effects of uncertainty, whereas countries low in UA would feel more comfortable in uncertain situations, having a better tolerance to risk (Qu and Yang, 
2015). Hwang and Lee (2012, p.172), emphasised "the need for formal rules and structure in the workplace and personal relationships" to manage uncertain situations.

As the level of anxiety and worry increases, the frequency of falling into uncertainty will also increase (Oltedal et al., 2004). Especially in societies where social risks are high, the frequency of uncertainty of individuals increases relatively (Wildavsky and Dake, 1990). In societies that are more exposed to the negative effects of risks, the tendency to avoid uncertainty will increase in this sense (Frijins et al., 2013).

\section{Situational Abnormality (SA)}

Drawing on the E-commerce literature, SA refers to the structures or conditions in the environment that affects the development of relational outcomes (McKnight et al; 1998; 2002; Gefen et al, 2003). McKnight et al (2002, p.478) identified two primary conditions: "situational normality" and "structural assurance". Structural assurance refers to believe that structures related to organisational or state systems are in place to promote relationship success or a positive desired outcome (McKnight et al; 1998; 2002). Normality conditions denotes stable or favorable conditions put in place to ensure relationship success (McKnight et al; 1998; 2002).

Conversely, SA takes a reverse notion by theorizing that conditions marred with betrayal, uncertainty and insecurity would most likely lead to negative outcomes (Schul et al. 1996, 2004, 2008; Moody, Galleta and Lowry, 2014). A situation as such is known as an abnormal setting (McKnight et al (1998). For example, when a country's insurance sector is fundamentally known to charge high premium insurance policy and fails to support customer claims, this would inevitably be seen in the light as abnormal setting. SA breeds customer suspicion relating to customer doubting the sincerity or motivations of the service provider (Hilton et al. 1993).

The term 'situational abnormality' refers to a state when a person perceives that something in relation to the provider is improper or abnormal (Schul et al.2008). Moody et al., (2014, p.268) identified four attributes of situational abnormality that are more specific than the general notion of normality: (1) general abnormalities (i.e., errors related to the general perception of the truster with regard to the normalcy of the situation); (2) informational abnormalities (i.e., errors related to the detailing of the product and its related information only); (3) process abnormalities (i.e., 
errors related to unexpected events during the buying process); and (4) design-related abnormalities (i.e., unexpected events or errors related to the design of the webpage itself).

It is an important determinant that the organizational field has a stable or dynamic structure in the emergence of situational abnormality (Edelman and Suchman, 1997). The organizational field represents all actors in which organizations interact in macro and micro level. While the stable structure of the field defines an environment where the number of legal regulations is small, change and innovation are weak, and political repression is minimal, the dynamic nature of the field emphasizes legal and political pressures and change are at a high level for that sector/industry. In dynamic structure of environment, law appears as a system of concrete regulations that enacts social authority on various aspects of organization life. The legal system takes initiative in order to change organizational behavior. While laws appear as a product of political thought, organisations aim at developing various strategies against this political force (Oliver, 1991). Hence, there is a power struggle between the state and professional unions and their administrators. The state and politicians are the most significant influencers of the stability and change in organizational field (Fligstein, 1991).

In societies with the dynamic structure of the insurance system, such as Turkey, governments are more inclined to reduce situational anomalies through legislation (Kırkbeşoğlu, 2012). The reason for governments' intervention in business life through legislation is an effort to reduce situational abnormalities. In sectors where the need to increase confidence, such as the insurance system, is high, the planned intervention of lawmakers will have a minimizing impact on situational abnormalities.

\section{Satisfaction}

The literature has two prevalent approaches in explaining customer satisfaction. One approach is the transaction specific and the overall satisfaction (Bodet, 2008; Lam et al., 2004; Johnson et al., 2001; Jones and Suh, 2000; Olsen, 2007; Veloutsou et al., 2005). The second approach is the confirmation and disconfirmation paradigm (Homburg et al., 2001; Homburg, Koschate and Hoyer, 2005; Oliver, 1997). The concept of transaction-specific satisfaction relates to a customer evaluation of one time encounter with various aspects associated with the business service provider (Jones and Suh, 2000). In contrast to the transaction-specific approach, the cumulative approach 
delineates satisfaction from the summative perspective of customer evaluation of the services provided (Homburg et al., 2005; Johnson et al., 2001).

Alternatively, confirmation and disconfirmation framework explicates how customer satisfaction develops (Fournier and Mick, 1999; Homburg et al., 2005; Oliva et al., 1992). This paradigm is dominant in the literature (Yi and Nataraajan, 2018). Customer satisfaction relates closely to how the performance of the services is able to fulfil the anticipated expectations (Evanschitzky et al., 2012; Oliva et al., 1992; Roman, 2003). With this performance and expectation evaluation, there are three fundamental perspectives to satisfaction (Oliva et al., 1992). The consumption of services is equivalent with the expectations (standards), in this case, confirmation of performance is established (Oliva et al., 1992; Roman, 2003). On the other hand, an expectation that is below the performance of the services leads to negative disconfirmation, while service performance above the customers' expectation level leads to positive disconfirmation (Oliver, 1980, Oliver 1997). Cogently, confirmation and positive disconfirmation will most likely influence customer to a state of satisfaction with a service provider (Oliver, 1997; Roman. 2003). In situation when customers have a positive disconfirmation, satisfaction will be the resultant outcome, whereas, in situation of negative disconfirmation, customer dissatisfaction and discontentment represents the possible resultant effects (Yi and Nataraajan, 2018).

\section{Trust}

The literature on trust has highlighted three main dimensions of trust; credibility, benevolence and the combination of both credibility and benevolence (Doney, Barry and Abratt, 2007; Ganesan, 1994; Singh and Sirdeshmukh, 2000).

The first approach conceptualises trust with the notion of credibility in an exchange partner (Coote et al., 2003; Morgan and Hunt, 1994). Trust is considered here to "exist when one party has confidence in the honesty, reliability, and integrity of their partner" (Coote et al., 2003, p. 597). Similarly, Morgan and Hunt (1994, p.23), defines trust as the "confidence in an exchange partner 's reliability and integrity”. In the same way, Nicholson et al. (2001, p.4) defined trust as the "confidence in the other party's reliability and integrity".

The second approach is the "confidence" dimension in the conceptualisation of trust (Ndubisi, 2011). The confidence in an exchange partner relates to the belief that such a partner in their 
business exchange is expected to be of high integrity and is reliable in delivering business promises. The confidence aspect to the conceptualisation of trust resonates with the cognitive dimension of trust identified by Johnson and Grayson (2005). According to Johnson and Grayson (2005), cognitive trust arises based on the level of knowledge accumulated about the service provider, which helps to eliminate risk and increase the level of confidence that the service provider will deliver on their promises and meet customer expectations.

The third approach conceptualised trust mainly as benevolence (Ganesan 1994). By definition, trust in the "partner's benevolence is a channel member's belief that its partner is genuinely interested in one's interests or welfare and is motivated to seek joint gains" (Geyskens et al., 1998, p.225). This aspect of trust accentuates the belief that the other party (trustee) will act in the best interest of the trusting party and will avoid taking actions that will impact negatively on the trustor. Importantly, benevolence trust reflects on the service provider having genuine interest in the welfare of his partner (Geyskens et al., 1998). Sirdeshmukh et al. (2002, p.18) noted that benevolence trust "reflects an underlying motivation to place the consumer's interest ahead of self-interest" of the service provider. Similar terms used to capture benevolence trust in the literature are business characteristic of good will, caring and responsiveness (McKnight and Chervany, 2002).

In the fourth approach, trust is conceptualised to integrate both the credibility and benevolence dimensions (Doney and Cannon, 1997). Consistent with Doney and Cannon (1997, p.36) view, trust is the "perceived credibility and benevolence of a target of trust". Similarly, Moorman et al. (1992, p.315) define trust as a business "willingness to rely on an exchange partner in whom one has confidence". Moorman et al. (1993, p.82) assert that for trust to exist, the dimensions of confidence and benevolence must be included in the definition of trust. They imply that "a person who believes that a partner is trustworthy and yet is unwilling to rely on that partner has only limited trust. Further, reliance on a partner without a concomitant belief about that partner's trustworthiness may indicate power and control more than it does with trust". The view of Moorman et al. $(1992 ; 1993)$ on the relevance of a trustor's willingness to rely on an exchange partner in times of uncertainty has resonance with the assertions of Blois (1999), Ganesan (1994) and Doney and Cannon (1997) that the existence of benevolence based trust under conditions of uncertainty reduces the exposure to vulnerability. trustThe literature on trust has highlighted three 
main dimensions of trust; credibility, benevolence and the combination of both credibility and benevolence (Doney, Barry and Abratt, 2007; Ganesan, 1994; Singh and Sirdeshmukh, 2000).

The first approach conceptualises trust with the notion of credibility in an exchange partner (Coote et al., 2003; Morgan and Hunt, 1994). Trust is considered here to "exist when one party has confidence in the honesty, reliability, and integrity of their partner" (Coote et al., 2003, p. 597). Similarly, Morgan and Hunt (1994, p.23), defines trust as the "confidence in an exchange partner 's reliability and integrity”. In the same way, Nicholson et al. (2001, p.4) defined trust as the "confidence in the other party's reliability and integrity".

The second approach is the "confidence" dimension in the conceptualisation of trust (Ndubisi, 2011). The confidence in an exchange partner relates to the belief that such a partner in their business exchange is expected to be of high integrity and is reliable in delivering business promises. The confidence aspect to the conceptualisation of trust resonates with the cognitive dimension of trust identified by Johnson and Grayson (2005). According to Johnson and Grayson (2005), cognitive trust arises based on the level of knowledge accumulated about the service provider, which helps to eliminate risk and increase the level of confidence that the service provider will deliver on their promises and meet customer expectations.

The third approach conceptualised trust mainly as benevolence (Ganesan 1994). By definition, trust in the "partner's benevolence is a channel member's belief that its partner is genuinely interested in one's interests or welfare and is motivated to seek joint gains" (Geyskens et al., 1998, p.225). This aspect of trust accentuates the belief that the other party (trustee) will act in the best interest of the trusting party and will avoid taking actions that will impact negatively on the trustor. Importantly, benevolence trust reflects on the service provider having genuine interest in the welfare of his partner (Geyskens et al., 1998). Sirdeshmukh et al. (2002, p.18) noted that benevolence trust "reflects an underlying motivation to place the consumer's interest ahead of self-interest" of the service provider. Similar terms used to capture benevolence trust in the literature are business characteristic of good will, caring and responsiveness (McKnight and Chervany, 2002).

In the fourth approach, trust is conceptualised to integrate both the credibility and benevolence dimensions (Doney and Cannon, 1997). Consistent with Doney and Cannon (1997, p.36) view, trust is the "perceived credibility and benevolence of a target of trust". Similarly, Moorman et al. 
(1992, p.315) define trust as a business "willingness to rely on an exchange partner in whom one has confidence". Moorman et al. (1993, p.82) assert that for trust to exist, the dimensions of confidence and benevolence must be included in the definition of trust. They imply that " a person who believes that a partner is trustworthy and yet is unwilling to rely on that partner has only limited trust. Further, reliance on a partner without a concomitant belief about that partner's trustworthiness may indicate power and control more than it does with trust”. The view of Moorman et al. $(1992 ; 1993)$ on the relevance of a trustor's willingness to rely on an exchange partner in times of uncertainty has resonance with the assertions of Blois (1999), Ganesan (1994) and Doney and Cannon (1997) that the existence of benevolence based trust under conditions of uncertainty reduces the exposure to vulnerability. trustThe literature on trust has highlighted three main dimensions of trust; credibility, benevolence and the combination of both credibility and benevolence (Doney, Barry and Abratt, 2007; Ganesan, 1994; Singh and Sirdeshmukh, 2000).

The first approach conceptualises trust with the notion of credibility in an exchange partner (Coote et al., 2003; Morgan and Hunt, 1994). Trust is considered here to "exist when one party has confidence in the honesty, reliability, and integrity of their partner" (Coote et al., 2003, p. 597). Similarly, Morgan and Hunt (1994, p.23), defines trust as the "confidence in an exchange partner 's reliability and integrity”. In the same way, Nicholson et al. (2001, p.4) defined trust as the "confidence in the other party's reliability and integrity".

The second approach is the "confidence" dimension in the conceptualisation of trust (Ndubisi, 2011). The confidence in an exchange partner relates to the belief that such a partner in their business exchange is expected to be of high integrity and is reliable in delivering business promises. The confidence aspect to the conceptualisation of trust resonates with the cognitive dimension of trust identified by Johnson and Grayson (2005). According to Johnson and Grayson (2005), cognitive trust arises based on the level of knowledge accumulated about the service provider, which helps to eliminate risk and increase the level of confidence that the service provider will deliver on their promises and meet customer expectations.

The third approach conceptualised trust mainly as benevolence (Ganesan 1994). By definition, trust in the "partner's benevolence is a channel member's belief that its partner is genuinely interested in one 's interests or welfare and is motivated to seek joint gains" (Geyskens et al., 1998, p.225). This aspect of trust accentuates the belief that the other party (trustee) will act in the best 
interest of the trusting party and will avoid taking actions that will impact negatively on the trustor. Importantly, benevolence trust reflects on the service provider having genuine interest in the welfare of his partner (Geyskens et al., 1998). Sirdeshmukh et al. (2002, p.18) noted that benevolence trust "reflects an underlying motivation to place the consumer's interest ahead of self-interest" of the service provider. Similar terms used to capture benevolence trust in the literature are business characteristic of good will, caring and responsiveness (McKnight and Chervany, 2002).

In the fourth approach, trust is conceptualised to integrate both the credibility and benevolence dimensions (Doney and Cannon, 1997). Consistent with Doney and Cannon (1997, p.36) view, trust is the "perceived credibility and benevolence of a target of trust". Similarly, Moorman et al. (1992, p.315) define trust as a business "willingness to rely on an exchange partner in whom one has confidence". Moorman et al. (1993, p.82) assert that for trust to exist, the dimensions of confidence and benevolence must be included in the definition of trust. They imply that "a person who believes that a partner is trustworthy and yet is unwilling to rely on that partner has only limited trust. Further, reliance on a partner without a concomitant belief about that partner's trustworthiness may indicate power and control more than it does with trust". The view of Moorman et al. $(1992 ; 1993)$ on the relevance of a trustor's willingness to rely on an exchange partner in times of uncertainty has resonance with the assertions of Blois (1999), Ganesan (1994) and Doney and Cannon (1997) that the existence of benevolence-based trust under conditions of uncertainty reduces the exposure to vulnerability.

\section{Loyalty}

The literature appears to have prevalently classified loyalty into three different perspectives (Dimitriades, 2006; Knox and Walker, 2001; Rauyruen and Miller, 2007). These are the behavioural perspective (Ehrenberg and Goodhardt, 2000; Olsen, 2007; Rauyruen et al., 2009), the attitudinal perspective (Shankar et al., 2003), and the composite perspectives (Ball et al., 2004; Bell and Eisingerich, 2007; Day, 1969; Dick and Basu, 1994; Kumar and Shah, 2004; Oliver, 1999).

The behavioral loyalty approach views the concept as a repetitive buying routine. In this approach, consumers' behavioural loyalty is operationalised as repeat purchasing or customer retention (Davis-Sramek, et al. 2009; Picon, Castro and Roldan, 2014; Reichheld, 1994). The stability and 
frequency of consumers repeat buying behaviours, enable researchers and practitioners to understand and predict future buying patterns of customers (Knox and Walker, 2001).

Alternatively, attitudinal loyalty focuses on the psychological dimensions of customer attitude to the service provider. Various researchers have used different attitudinal themes to operationalise the attitudinal perspectives of loyalty. For instance, Rauyruen and Miller (2007, p.23) defined attitudinal loyalty as "the level of customer's psychological attachments and attitudinal advocacy towards the service provider/supplier". From this definition, the integration of positive word of mouth and willingness to recommend underpins the concept of attitudinal loyalty (Cater and Cater, 2010; Evanschitzky et al., 2006).

A different perspective to the attitudinal or behavioural loyalty approach is the composite loyalty perspective (Dick and Basu, 1994; Hutchinson et al., 2011; Oliver, 1997, 1999; Wallace, Giese and Johnson, 2004). This approach enables the integration of both the attitudinal and behavioural elements in the conceptualisation of loyalty (Caceres, and Paparoidamis, 2007). Academics commonly construct loyalty as both attitudinal and behavioural (Beerli et al., 2004; Brunner, Stocklin and Opwis, 2008; Rauyruen and Miller, 2007). According to Oliver (1999, p.34), loyalty is defined as "a deeply held commitment to rebuy or repatronise a preferred product and service consistently in the future, thereby causing repetitive same-brand purchasing, despite situational influences and marketing efforts having the potential to cause switching behaviour'. Oilver's definition endorses the idea that loyalty has attitudinal and behavioural components (Beerli et al., 2004; Brunner et al., 2008). The author's specifically infer the attitudinal component of loyalty as commitment that propels consistency in repatronising from the same brand or services.

\section{Research Conceptual Framework and Hypothesis}

The research conceptual framework is developed by integrating the theory of social exchange (SET) (Blau, 1964), institutional-trust factors (McKnight et al; 1998; 2002) and Zones of Tolerance (ZOT) effect. The ideology of Blau (1964, p.91) is that social exchange are "voluntary actions of individuals that are motivated by the returns they are expected to bring from others". In particular, SET support social values attributes such as emotional satisfaction, spiritual values, trust, and harmony (Lambe, Wittman and Spekman, 2001). SET ideology is reinforced by affect theory of social exchange (Lawler, 2001) that posits that in a social exchange interaction, partners 
make effort to increase positive emotions and to reduce negative emotions, in turn enhancing relationship sustainability.

The theory of social exchange appears to be the framework that underpins B2C relational studies with hypothesized positive relationship between satisfaction, trust and loyalty (Castan eda, 2011; Fullerton, 2011). With this established backbone, this research proposes that in situations of harmonious relationship between the customers and insurance service provider, satisfaction will lead to even greater harmony and deeper sense of relationship continuity based on this notion, the study hypotheses the following:

H1: Satisfaction is related positively to trust.

$\mathrm{H} 2$ : Trust is related positively to loyalty.

\section{Figure 1: Research Theoretical Model}

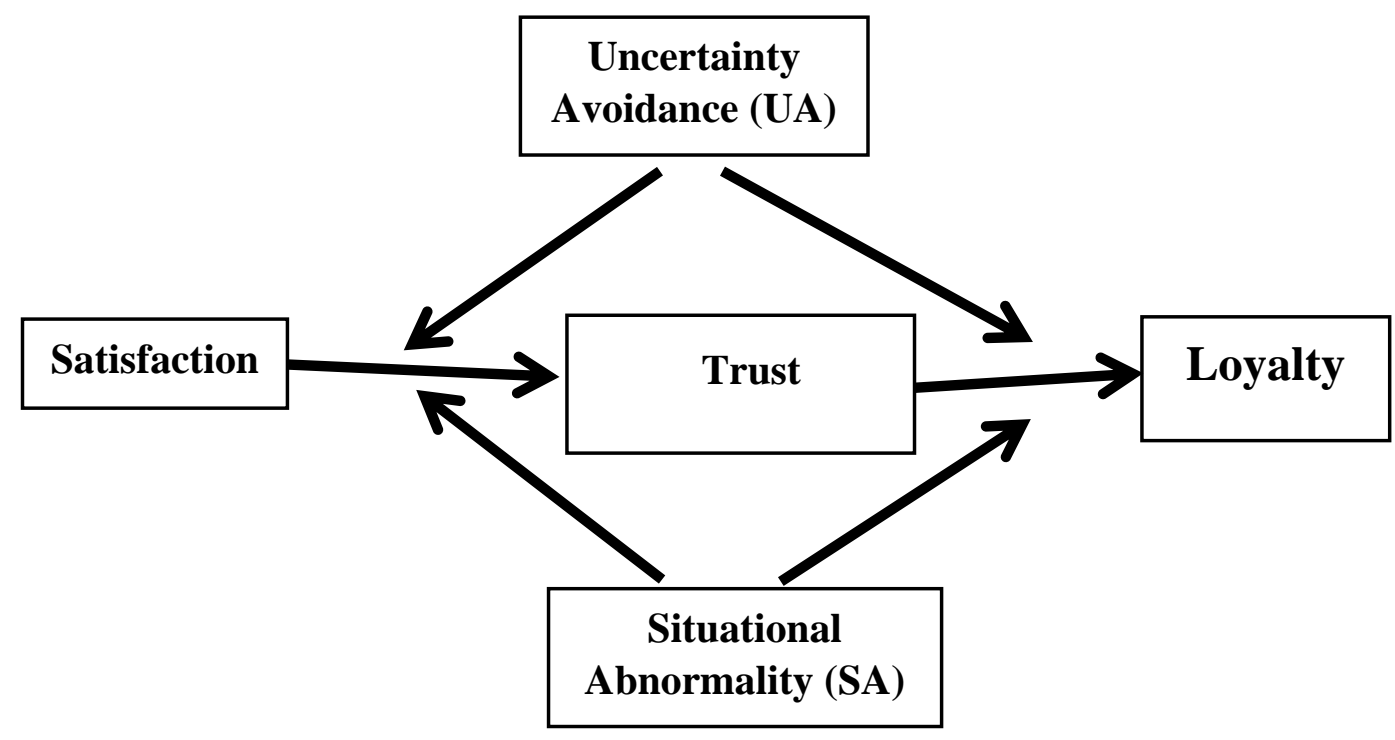

McKnight (1998; 2002) influenced from sociology on structural conditions constructed institutional-trust factors that considers the environment in which relationship may develop. Drawing from the e-commerce literature on abnormality conditions (McKnight (1998; 2002; Schul et al.2008; Moody et al., 2014), the research proposes that the environmental factors that underpins relational settings will influence the direction and strength of the relationship. In Turkey, the insurance demand has remained very low for many years because of legal gaps in the insurance 
system. Insurance companies had some advantages in relation to using legal gaps. Many insurance disputes resulted in favor of insurance companies. The lack of a guiding system of insurance has increased the victims of the insured. All these situational abnormalities seemed to have an effect on the attitude of policyholders concerning trust and loyalty towards insurance companies in Turkey. Based on the situational abnormality effect, the research hypothesises that SA will endanger relationship in the following ways:

H3: Situational abnormality will negatively moderate the relationship between satisfaction and trust.

H4: Situational abnormality will negatively moderate the relationship between trust and loyalty.

Ndubisi (2004) stated that cultures high in UA would prefer relationship marketing as opposed to transactional marketing. Reimann, Lünemann and Chase (2008), argued that the higher the degree of UA, the stronger tendency for perceived service quality on customer satisfaction as opposed to low level of UA. The theoretical proposition is based on the concept of Zones of Tolerance (ZOT) effect, which proposes that customers with high levels of UA tend to have low tolerance to risk, with the tendency to seek service provider with clear structure, accessible and accurate information (Reimann et al., 2008). Based on Reimann et al., (2008) line of thought and the ZOT concepts, the research hypothesises UA will engender positive relationship quest in the following ways:

H5: High level of uncertainty avoidance will positively moderate the relationship between satisfaction and trust.

H6: High level of uncertainty avoidance will positively moderate the relationship between trust and loyalty.

\section{Methodology}

\section{Turkey Insurance Context}

To explore the focal phenomena, the study used a cross-cultural setting; based on the Turkish insurance industry. The research context represents a unique context in terms of situational abnormality and uncertainty avoidance. Until 2005, the Turkish insurance sector had a chaotic structure. Due to the lack of an effective legal system, insurance companies have used legal gaps 
against the policyholders. The lack of knowledge of the public about insurance on the one hand and the lack of a legal system to protect the insured on the other hand has led to the loss of the insured. Especially in the 1990s, a large number of policyholders were exposed to injustice due to the differentiation in insurance policies, the depreciation of the sum insured due to high inflation and the insolvency of the insurance companies that do not have strong financial infrastructure. The absence of any legal regime before the establishment of the insurance company, the dominance of the government and military in business, led to the management of insurers who did not understand insurance. In addition, these situational abnormalities have weakened the use of insurance systems as a means of avoiding uncertainty in Turkey. In sum, the absence of a legal system to protect insured people has caused to a long-standing confidence crisis against the insurance system.

Besides, Turkey insurance sector growth is not parallel with EU economic growth. EU - Turkey relationships, based on a history of more than forty years, have accelerated, with full membership negotiations starting in 2005. Following these, it was required that the insurance industry gain a quality appropriate to EU norms. The government has implemented important revisions in the last decade due to progress in the insurance industry being less than expected. During this period, insurance law was re-written, the pool systems were established and it was ensured that, by establishing insurance information centers, meaningful statistics were collected on, for example, insurance fraud and non-insurance. Also, new organizations (e.g. Insurance Education Centre) were created to make insurance training more common and several adverts and promotions regarding insurance appeared in social media and the public spotlight. Another example of the government's increasing interest in the insurance industry is the individual retirement system. The government transferred the operation of this system to the life insurance sector and offered considerable support to participants (25\% additional premium support, tax advantage etc.). Also, in order to protect the insured, Solvency II criteria came into force regarding financial competency, capital competency, liability-meeting competency and payment power. Additionally, significant amendments were made in insurance law regarding insurance sales and marketing.

Despite the Turkish government's efforts to develop the insurance sector in the last decade, insurance penetration is still far behind the European Union average. For example, while the average insurance premium in 2016 in the EU countries was approximately $\$ 2,800$ per person, it was around $\$ 162$ in Turkey, lower than the world average of $\$ 621$ (Insurance Association of 
Turkey, 2016). Also, Turkey is in the last rank among 33 OECD countries (OECD Statistics, 2016). While the share of insurance premiums in relation to gross national product in the EU countries is $8 \%$, it is around $1.5 \%$ for Turkey (OECD Statistics, 2016). In addition to this, total premium income in Turkey in 2016, with a population of 79 million, was around $\$ 12.3$ billion, less than countries with much smaller populations (Insurance Association of Turkey, 2016). In brief, although Turkey reached the success of 'the world's fastest growing economy' in the first quarter of 2011, it does not appear to have supported its success with a substantial insurance industry.

As identified by Hofstede's insight, Turkey has a high value score pertaining to risk and uncertainty about the future (Hofstede, Hofstede, and Minkov 2010). Additionally, taking insurance policy is typically set up to mitigate against such risk. Considering, the national trait of UA in Turkey and the need to mitigate risk, the UA factors is pivotal how relationship is formed, developed, and maintained in Turkey's insurance sector.

\section{Questionnaire design and procedure}

The study adopted a survey design approach using a sample size of 621 automobile policy insurance holder of a local based insurance company in Isparta City, Southwestern Turkey. This City was chosen because of its thriving economic activities centered on forestry and agriculture, manufacturing industry, community, social and personal services (Turkish Statistical Institute, 2000). In addition, one of the researchers had access to the company and familiar with the local culture, which was supportive at the piloting stage and data collection process.

The research instruments were adapted from existing scales measured within a 7-point Likert scale ranging from very strongly agreed (7), neutral (4) and very strongly disagreed (1). The questionnaire contained 26 items drawn from previous literature and adapted to the research context. SA items were adapted from Moody, Galleta and Lowry, (2014); UA items were derived from (Sampaio, Ladeira and Santini, 2017 and Hwang and Lee, 2012). Satisfaction items were adapted from Lam et al. (2004), Trust items from (Coote, Forrest, and Tam, 2003; Ball, Coelho and Machas, 2004 and Cater and Cater, 2010) and finally, Loyalty items from (Fullerton, 2005; Keh and Xie, 2009) (full measurement items summarised in Appendix one). Each of these items evaluates the customers perception of services received at the insurance agency. 
Initially, the survey was designed in English before been translated to Turkish language for face validation process to ensure readability and understandability of the survey. This procedure was essential to help minimize the effect of common method biase caused by ambiguous questions. The authors followed Tourangeau et al (2000) recommendations by following the process of items improvement. An academic and three local industry experts who speaks the Turkish native language fluently were involved in simplifying of vague and ambiguous scale items. Furthermore, survey pilot testing process was conducted with two Turkish native customers who read the items checking for clarity and understanding. The pilot process led to minor adjustment of the research instruments.

In addition, the authors adhered to Podsakoff et al (2003) suggestion of respondent anonymity to reduce the effects of common method biase. As a process, respondents completing the survey were reassured of data anonymity and encouraged to fill the survey only based on the item questions without any form of social desirability or wanting to please or gain approval from the research assistants. Furthermore, the survey was not counter-balance as recommended that Podsakoff et al (2003), that cause and effect variables should not be presented in a predictive way so the respondents would not preempt and respond to questions without careful thought and objective respond to the questions. The authors counter-balanced the survey by placing the measurements items in this order; satisfaction, situational abnormality, uncertainty avoidance, loyalty and trust.

The insurance agency supported the data collection by employing two experts both of whom are Turkish female with familiarity with the local culture in Isparta. Subsequently, the research assistants randomly distributed hardcopies of the designed questionnaire to customers who visited the insurance agency in Isparta City, Southwestern Turkey.

Although respondents' answers were kept anonymous and confidential, the research assistant made a list of the customers who completed the questionnaire in order to avoid the risk of gathering data from the same respondent. The whole procedure of data collection took six weeks in collaboration with the insurance agency.

Out of 250 distributed surveys, 206 were collected; however, 6 surveys were eliminated due to missing data, reducing the useable data set to 200, representing a useable survey response rate of $80 \%$. 


\section{Demographic Analysis:}

The demographic data comprised of age and relationship length. Table 1 below statistically represents the respondent attributes composition. In terms of age, the highest represented age group were policyholders between the ages of 26 to 35 , representing 54 respondents and $27 \%$ of the total sample. While for longest relationship length, 1-3 years represented the highest; 83 respondents and $41.5 \%$ of the total sample.

Table 1.0: Data Demographics

\begin{tabular}{|c|c|c|c|}
\hline Variables & Category & Sample & Percentage \\
\hline \multirow[t]{7}{*}{ Age (years) } & under 18 & 1 & $0.5 \%$ \\
\hline & $18-25$ & 50 & $25 \%$ \\
\hline & $26-35$ & 54 & $27 \%$ \\
\hline & $36-40$ & 30 & $15 \%$ \\
\hline & $41-55$ & 41 & $20.5 \%$ \\
\hline & $56-65$ & 15 & $7.5 \%$ \\
\hline & above 65 & 9 & $4.5 \%$ \\
\hline \multirow{5}{*}{$\begin{array}{l}\text { Length of being a } \\
\text { customer (years) }\end{array}$} & under 1 & 58 & $29 \%$ \\
\hline & $1-3$ & 83 & $41.5 \%$ \\
\hline & $4-7$ & 38 & $19 \%$ \\
\hline & $8-11$ & 14 & $7 \%$ \\
\hline & above 11 & 7 & $3.5 \%$ \\
\hline
\end{tabular}

\section{Data Analysis}

The research used the two-stage approach recommended by Anderson and Gerbing (1988) and Hair et al. (2010) for model validation and structural relationship assessment. Stage one entails measurement model validity and goodness of fit assessment by employing the CFA technique. The second stage of analysis involved the application of SEM to evaluate the research structural model by using the Maximum Likelihood (ML) estimation method.

\section{Constructs Validity Assessment}


Table 2.0 - Convergence Validity Assessment: Standard Factor Loading, AVE: Average Variance Extracted, CA: Cronbach's Alpha

\begin{tabular}{|c|c|c|c|c|}
\hline Constructs & Indicators & $S F L$ & $A V E$ & $C R$ \\
\hline Trust & $\begin{array}{l}\text { 1) Promises made by my insurance company are reliable. } \\
\text { 2) My insurance company treats me in an honest way } \\
\text { about my policy enquiry. } \\
\text { 3) In times of uncertainty and vulnerability, my insurance } \\
\text { company has my best interests in mind. } \\
\text { 4) I have great confidence in my insurance company. } \\
\text { 5) My insurance company is genuinely concerned about } \\
\text { my driving safety. }\end{array}$ & $\begin{array}{l}0.83 \\
0.86\end{array}$ & 0.79 & 0.89 \\
\hline Loyalty & $\begin{array}{l}\text { 1) I will spend more money to buy additional insurance } \\
\text { policy. } \\
\text { 2) I will recommend my insurance broker to other people } \\
\text { that seek my advice. } \\
\text { 3) I say positive things to other people about my } \\
\text { insurance broker. } \\
\text { 4) I will continue to buy insurance policy from my broker } \\
\text { in the next few years. }\end{array}$ & $\begin{array}{l}0.52 \\
0.90\end{array}$ & 0.77 & 0.83 \\
\hline $\begin{array}{l}\text { Situational } \\
\text { Abnormality }\end{array}$ & $\begin{array}{l}\text { 1) I do not feel good about the automobile insurance } \\
\text { policy in Turkey. } \\
\text { 2) I would feel uncomfortable purchasing the insurance } \\
\text { policy offered. } \\
\text { 3) I do not believe that the automobile policy provided } \\
\text { to me is correct. } \\
\text { 4) The buying process of my automobile policy } \\
\text { included things I did not expect. } \\
\text { 5) The automobile insurance policy offered is not } \\
\text { complete. }\end{array}$ & $\begin{array}{l}0.93 \\
0.77\end{array}$ & 0.81 & 0.88 \\
\hline Satisfaction & $\begin{array}{l}\text { 1) In general, I am very satisfied with my insurance } \\
\text { company. } \\
\text { 2) Overall, it has been good to have my car insured with } \\
\text { my insurance company. } \\
\text { 3) Overall, the policy of my insurance company meets } \\
\text { up to my expectations. } \\
\text { 4) Overall, my insurance company treats me very fairly. }\end{array}$ & 0.84 & 0.85 & 0.88 \\
\hline $\begin{array}{l}\text { Uncertainty } \\
\text { Avoidance }\end{array}$ & $\begin{array}{l}\text { 1) It is important for my insurance company to have } \\
\text { instructions explained in detail. } \\
\text { 2) Government rules and regulations are important } \\
\text { because they inform me of the appropriate automobile } \\
\text { insurance policy to buy. } \\
\text { 3) It is important to buy the suitable insurance policy for } \\
\text { my circumstance. } \\
\text { 4) Comprehensive insurance policy is helpful. }\end{array}$ & 0.71 & 0.77 & 0.91 \\
\hline
\end{tabular}


5) Clear instructions from my insurance company are $\quad 0.85$ important.

6) Insurance companies should make sure to inform $\quad 0.74$ customers about their rights according to the government rules and regulations.

Following the removal of problematic constructs as a result of factor loading and goodness of fit issues, the remaining constructs are within the acceptable thresholds for factor loadings (above 0.50), AVE (above 0.50) and reliability acceptance (above 0.70). Based on these outcomes, the identified constructs are regarded as convergent valid.

\section{Discriminant Validity Assessment}

The most rigorous assessment of discriminant validity is when the Average Variance Extracted (AVE) is greater than the Square Inter-Correlation (SIC) (Farrell, 2010; Hair et al., 2010). AVE is the sum average mean value of the total factor loadings of the measurement items to a construct (Hair et al., 2010), while the SIC represents the shared variance of correlation between the two constructs being measured. Table 3.0 suggests that the relational variable AVEs are larger when compared to all other alternative paired squared correlations. Therefore, in accordance to Farrell (2010) and Hair et al., (2010), the result has established sufficient discriminant validity amongst the research factors.

Table 3.0: Constructs Discriminant Validity Assessment

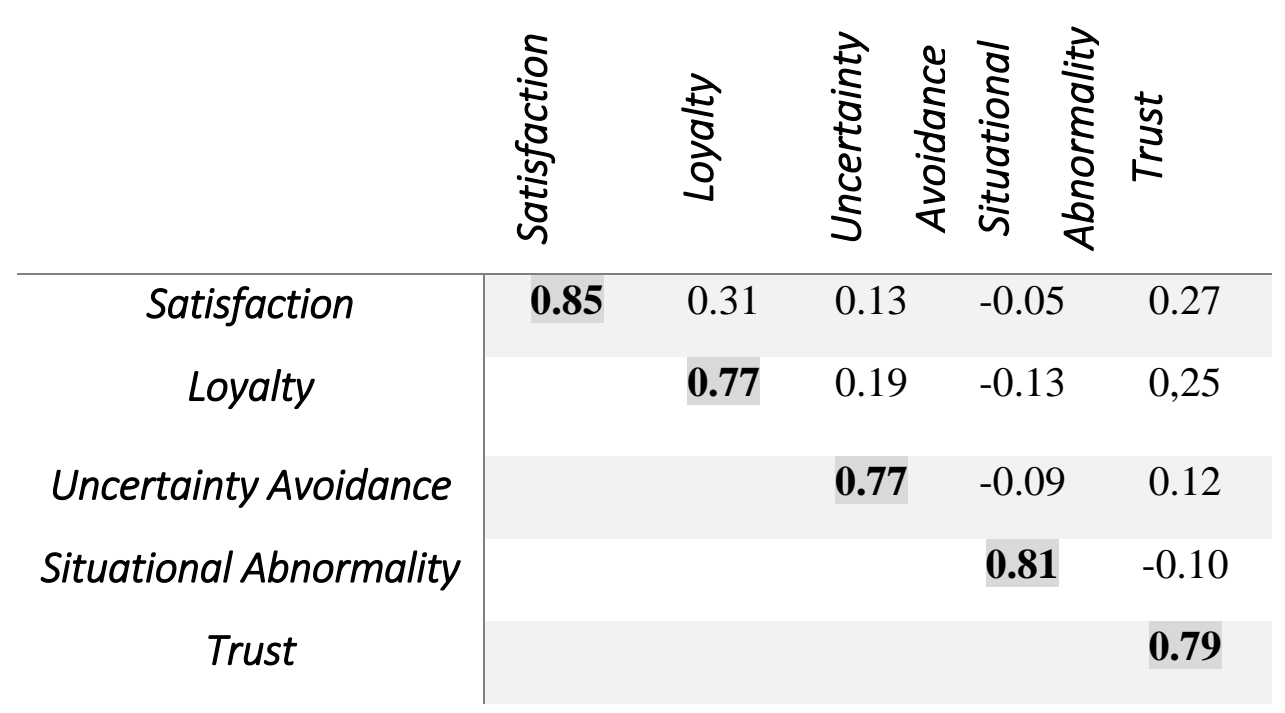


Note: the diagonal values represent the Average Variance Extracted (AVE) estimates, while the values above the AVE represent the Squared Inter-Correlations (SIC).

\section{Goodness of Fit Assessment}

For model fit, the normed chi-squared statistic $\left(X^{2} / \mathrm{df}\right)$ is 1.02 [below 3], the goodness of fit statistics are GFI $=0.92, \mathrm{CFI}=0.99$ and TLI $=0.99$ [all higher than 0.9], with $\mathrm{RMSEA}=0.01$ [below 0.08]. This suggests that the amended model has a suitable fit. It is possible to move to stage two to assess the relationship paths using SEM.

Model 1: Interaction Effect

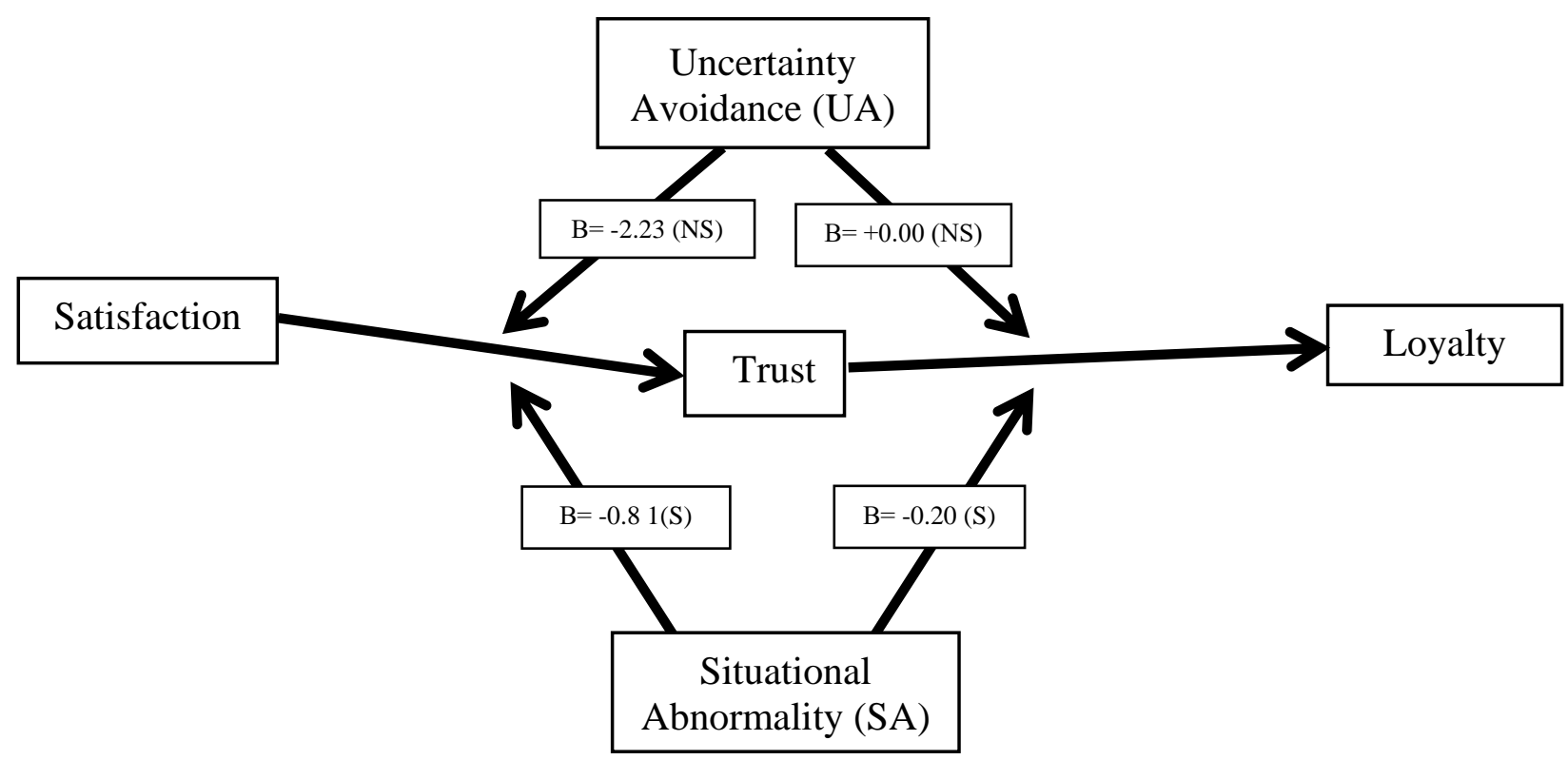

Note: $\mathbf{S}=$ Supported; $\mathbf{N S}=$ Not supported.

Model 2: Non-Situational Effect (Alternative Model)

The alternative model goodness of fit was assessed using AMOS analysis. The result indicated an acceptable fit with normed chi-squared statistic $\left(X^{2} / \mathrm{df}\right)$ is 1.75 [below 3], the goodness of fit statistics are GFI $=0.92, \mathrm{CFI}=0.97$ and $\mathrm{TLI}=0.96$ [all higher than 0.9], with $\mathrm{RMSEA}=0.06$ [below 0.08]. This suggests that the alternative model still has a suitable fit. Hence, the author performed structural assessment of the relationship paths using SEM. 


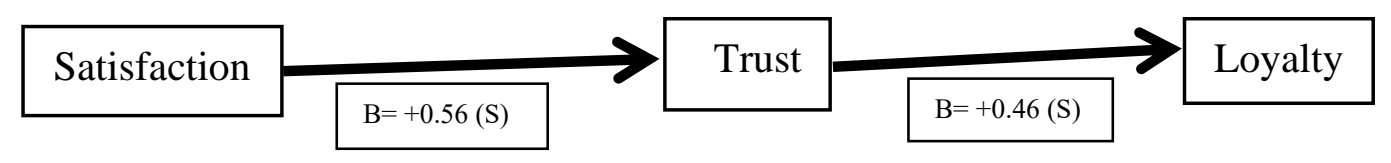

Table 4.0. Representation of Hypotheses Results

\section{Hypothesis}

\section{None Situational Effect}

$\mathrm{H} 1$ Satisfaction $\longrightarrow$ Trust

$\mathrm{H} 2$ Trust $\longrightarrow$ Loyalty

\section{Situational Effect}

H3 SA x Satisfaction $\longrightarrow$ Trust

$\mathrm{H} 4 \mathrm{SA} x$ Trust $\longrightarrow$ Loyalty

H5 UA x Satisfaction $\longrightarrow$ Trust

H6 UA x Trust $\longrightarrow$ Loyalty

\section{Path Coefficient}

0.00

Yes

$+0.46$

0.00

Yes

$-0.81$

0.04

Yes

$-0.20$

0.01

Yes

$-2.23$

0.00

No

$+0.00$

0.85

No

\section{Discussion and Conclusion}

The study assessed the effect of UA and SA on satisfaction - trust - loyalty relational strand in the Turkey automobile insurance sector. To assess the interaction effects, the study presented and analysed a pivotal model with associated interaction effects of UA and SA, and a rival model without interaction effects describing only the relational link of satisfaction - trust - loyalty. Using primary data collected from 200 customers (policyholders) of various automobile insurance service providers, the study employed CFA and SEM analyses to determine the effects of interaction and non-interaction effects.

Although UA was not significant, the study finds strong support on SA relationship values (McKnight et al; 1998; 2002; Schul et al. 1996, 2004, 2008; Moody et al., 2014). To begin with, the alternative model without interaction effects $(\mathrm{H} 1$ and $\mathrm{H} 2)$ were positive and strongly supported. This shows that with the absent of interaction effects, relationship has a stronger tendency to be smooth and sustained. The alternative model relationship strength supports relationship scholars on satisfaction - trust - loyalty studies (Morgan and Hunt, 1994; Doney and Canon, 1997; Doney, Barry, \& Abratt, 2007; Sekhon et la., 2013; Kharouf, Lund, and Sekhon, 2014). 
In contrary, the pivotal relationship model showed that the presence of interaction effect led to disturbed relational outcomes. H3 proposes SA will negatively moderate satisfaction and trust relationship was supported. The current condition of the insurance industry demonstrate why the relationship is negative, as people feel more negative about the sector, their confidence towards the integrity and honesty of the automobile insurance provider is devalued. The level of trust against the insurance system in Turkey for many years has remained low.. More precisely, the environment of insecurity seemed to have contributed to the devalued trust relationship. Similarly, $\mathrm{H} 4$, that examines the interactive effect of SA and trust on loyalty had a negative outcome. This finding indicates that when there is the presence of doubts and negative feelings about the sector, the insurance customers' loyalty towards their policy provider is hampered. The finding supports e-commerce literature proposition that abnormal or unfavorable business environment endangers positive relationship outcomes (Schul et al. 1996, 2004, 2008; Moody et al., 2014).

UA interaction with satisfaction led to a negative effect on trust (H5), contrary to the hypothesised positive relationship. Perhaps, the negative relationship suggests high level of UA culture is not significant to the relationship development of customers trust and loyalty to their insurance policy providers. Similarly, the interaction effect of UA and trust on loyalty was not supported (H6). Perhaps, the finding is an indication that the insurance sector still lacks quality services to foster customer's confidence and integrity in their services provider.

\section{Theoretical and Practical Contribution}

This research finding makes notable and interesting contribution to the business service-oriented research. Importantly, the research is the first to develop a relational conceptual framework that integrates SA and UA to examine the effect on the relational link of satisfaction - trust - loyalty. By developing this model, academics have access to newly formed relational model to examine other contextual settings where there are emerging evidence of situational abnormalities. Next, the research has proven that in the presence of extenuating factors, the dominant relationship strand is prone to distortion resulting to either insignificant or weak relational values between the customers and service provider. Therefore, this study argues that although UA was not predictive in the model, SA demonstrated high distortion effects, which is important to further studies in both B2B and B2C relationships. More importantly, the introduction of SA concept in relational marketing 
studies has received little attention since developed by McKnight et al, (1998, 2002). The study calls for more marketing academics to consider SA as an important "construct" when investigating relationship value models, as this research echoes the crucial role SA plays to moderate relationship development as highlighted in the e-commerce literature (McKnight et al; 1998; 2002; Gefen et al, 2003; Schul et al. 1996, 2004, 2008; Moody et al., 2014).

In terms of business relevance, the study has some remarkable findings useful to the insurance industry. As Turkey is high on UA orientation, there is the need for insurance policy maker to have clear systems and structures to support policyholders in such a way that risks and uncertainty are minimized. For example, writing policy using simple language that potential automobile policyholder will find it easy to comprehend. This should be supported with a robust customer services that takes time to explain insurance policy before signed by customer. Taking this approach, will position the insurance policy provider in a positive light thereby fostering stronger tie between the customer and service provider. Furthermore, businesses in the insurance sector should be more responsive to the policyholder claims in a manner that is respectful and supportive. Perhaps, this approach provides the much-needed support that can mitigate against SA in area related to customer doubts associated to claim and process complexity. Similarly, to reduce UA effect, insurance policy provider should be seem as responsible and supportive to customers involved in accidents particularly in situations when it is established that the policy holder is not at fault.

There are new research opportunities emerging from this study. An important and urgent area is to replicate the research model and empirically test it in different relational settings to establish the explanatory robustness of the model. For instance, what would be the effect of satisfaction trust - loyalty in settings described to have low and modest levels of UA such as China and United Kingdom respectively? Furthermore, what would be the SA and UA effects on industrialised nations with fairly developed and stable insurance sector? This is a crucial question when considering such societies level of UA and anticipated tolerance risk level as depicted by Hofstede cultural dimensions.

As a limitation to the study, the authors analysed the data homogenously without conducting analysis on demographics such as gender, relationship length, profession or family profile of the 
customers. There is value in extending the current research by considering demographic variables such as customer's income effect on the research model.

\section{References}

Akrout, H. (2015) "A process perspective on trust in buyer-supplier relationships. "Calculus": An intrinsic component of trust evolution", European Business Review, 27(1), pp.17-33.

Anderson, J. C., \& Gerbing, D. W. (1988). Structural equation modelling in practice: A review and recommended two-step approach, Psychological bulletin volume 103 (3), 411-423.

Ball, D., Coelho, P. S., \& Machás, A. (2004). The role of communication and trust in explaining customer loyalty: an extension to the ECSI model. European Journal of Marketing, 38(9/10), 1272-1293.

Bansal, H. S., Irving, P. G., \& Taylor, S. F. (2004). A three-component model of customer to service providers. Journal of the Academy of Marketing Science, 32(3), 234-250.

Bell, S. J., \& Eisingerich, A. B. (2007). The paradox of customer education: customer expertise and loyalty in the financial services industry. European Journal of Marketing, 41(5/6), 466-486.

Beerli, A., Martin, J. D., \& Quintana, A. (2004). A model of customer loyalty in the retail banking market. European Journal of Marketing, 38(1/2), 253-275.

Blau, P. M. (1964). Exchange and power in social life. New York: John Wiley.

Blois, K. J. (1999). Trust in business-to-business relationships: an evaluation of its status. Journal of Management Studies, 36(2), 197-215.

Bodet, G. (2008). Customer satisfaction and loyalty in service: Two concepts, four constructs, several relationships. Journal of Retailing and Consumer Services, 15(3), 156-162.

Brunner, T. A., Stöcklin, M., \& Opwis, K. (2008). Satisfaction, image and loyalty: new versus experienced customers. European Journal of Marketing, 42(9/10), 1095-1105.

Cater, T., \& Cater, B. (2010). Product and relationship quality influence on customer commitment and loyalty in B2B manufacturing relationships. Industrial Marketing Management, 39(8), 1321-1333.

Castañeda, J. A. (2011). Relationship between customer satisfaction and loyalty on the internet. Journal of Business and Psychology, 26(3), 371-383.

Davis-Sramek, B., Droge, C., Mentzer, J. T., \& Myers, M. B. (2009). Creating commitment and loyalty behavior among retailers: what are the roles of service quality and satisfaction? Journal of the Academy of Marketing Science, 37(4), 440-454.

Cho, J. (2006). The mechanism of trust and distrust formation and their relational outcomes. Journal of Retailing, 82(1), 25-35 
Chiou, J.S. and Droge, C. (2006), "Service quality, trust, specific asset investment, and expertise: direct and indirect effects in a satisfaction-loyalty framework", Journal of the Academy of Marketing Science, 34 (4), pp. 613-627.

Coote, L. V., Forrest, E. J., \& Tam, T. W. (2003). An investigation into commitment in nonWestern industrial marketing relationships. Industrial Marketing Management, 32(7), 595-604.

Coelho, F and Easingwood, C (2005) "Determinants of multiple channel choice in financial services: an environmental uncertainty model", Journal of Services Marketing, 19 (4), pp.199211.

Day, G.S (1969). two-dimensional concept of brand loyalty, journal of advertising research 9(9), $29-35$.

Dagger, T. S., \& O'Brien, T. K. (2010). Does experience matter?: Differences in relationship benefits, satisfaction, trust, commitment and loyalty for novice and experienced service users. European Journal of Marketing, 44(9/10), 1528-1552.

De Bellis, E., Hildebrand, C., Ito, K., \& Herrmann, A. (2015). Cross-national differences in uncertainty avoidance predict the effectiveness of mass customization across East Asia: A largescale field investigation. Marketing Letters, 26(3), 309-320.

Dick, A. S., \& Basu, K. (1994). Customer loyalty: toward an integrated conceptual framework. Journal of the Academy of Marketing Science, 22(2), 99-113.

Dimitriades, Z. S. (2006). Customer satisfaction, loyalty and commitment in service organizations: some evidence from Greece. Management Research News, 29(12), 782-800.

Doney, P. M., \& Cannon, J. P. (1997). An examination of the nature of trust in buyer-seller relationships. The Journal of Marketing, 61 (4),35-51.

Doney, P. M., Barry, J. M., \& Abratt, R. (2007). Trust determinants and outcomes in global B2B services. European Journal of Marketing, 41(9/10), 1096-1116.

Edgett Scott, and Parkinson Stephen (1993). "Marketing for Services Industries, A Review", The Services Industries Journal, July, Vol. 13 (3), pp. 19-39.

Edelman, L.B. ve Suchman, M.C. (1997). The Legal Environments of Organizations, Annual Review of Sociology, , Vol. 23: 479-515.

Elmas, M.S. (2013). The End of Security of Modern Society: Threat, Risk and Risk Society (Turkish: Modern Toplumun Güvenlik Çıkmazı: Tehdit, Risk ve Risk Toplumu). USAK Publication. Ankara.

Ehrenberg, A., \& Goodhardt, G. (2000). New brands: near-instant loyalty. Journal of marketing management, 16(6), 607-617.

Erdoğan, N. K. (2003). Farklı meslek gruplarının hayat sigortasına bakışı ve bireysel emeklilik sigortasının geleceği. Dumlupınar Üniversitesi Sosyal Bilimler Dergisi, 3(8). 
Evanschitzky, H., Iyer, G. R., Plassmann, H., Niessing, J., \& Meffert, H. (2006). The relative strength of affective commitment in securing loyalty in service relationships. Journal of Business Research, 59(12), 1207-1213.

Evanschitzky, H., Sharma, A., Prykop, C. (2012).The role of the sales employee in securing customer satisfaction, European Journal of Marketing, 46 (3/4), 489 - 508.

Farrell, A. M. (2010). Insufficient discriminant validity: A comment on Bove, Pervan, Beatty, and Shiu (2009). Journal of Business Research, 63(3), 324-327.

Fligstein, N. (1991). The Structural Transformation of American Industry: an Institutional Account of the Causes of Diversification in the Largest Firms, 1919-1979, Powell, W.W., ve P.J. DiMaggio (Edt.) The New Institutionalism in Organizational Analysis. Chicago: University of Chicago Press.

Fournier, S. \& Mick, D.G. (1999). Rediscovering Satisfaction, Journal of Marketing, 63(10), 523.

Frijns, B., Gilbert, A., Lehnert, T. and Tourani-Rad, A., (2013), Uncertainty Avoidance, Risk Tolerance and Corporate Takeover Decisions, Journal of Banking \& Finance, 37(7), pp.24572471.

Fullerton, G. (2005). The service quality-loyalty relationship in retail services: does commitment matter? Journal of Retailing and Consumer Services, 12(2), 99-111.

Fullerton, G. (2011). Creating advocates: the roles of satisfaction, trust and commitment. Journal of Retailing and Consumer Services, 18(1), 92-100.

Ganesan, S. (1994). Determinants of long-term orientation in buyer-seller relationships, The Journal of Marketing, 58 (2), 1-19.

Geyskens, I., Steenkamp, J.-B. E., \& Kumar, N. (1998). Generalizations about trust in marketing channel relationships using meta-analysis. International Journal of Research in Marketing, 15(3), 223-248.

Gökoğlu, M., Kırkbeşoğlu, E. ve Tuzlukaya, Ş. (2015). Role of Rhetorical Strategies in the process of institutionalization: A Qualitative Analysis on Institutionalization of the Insurance Sector in Turkey (Turkish: Kurumsallaşma Sürecinde Retorik Stratejilerinin Rolü: Türkiye'de Sigortacılık Sektörünün Kurumsallaşması Üzerine Niteliksel Bir Analiz). Journal of Business Research Turk. 7(3), pp. 261-282.

Hair, J.F., Black, W.C., Babin, B.J., Anderson, R.E. (2010), Multivariate Data Analysis - A Global Perspective, 7th Edition, New jersey: Pearson Education.

Hilton, J.L., Fein, S., Miller, D.T., 1993. Suspicion and dispositional inference. Personality and Social Psychology Bulletin 19 (5), 501-512. 
Hutchinson, D., Wellington, W. J., Saad, M., \& Cox, P. (2011). Refining value-based differentiation in business relationships: A study of the higher order relationship building blocks that influence behavioural intentions. Industrial Marketing Management, 40(3), 465-478.

Hofstede, G., Hofstede, G. J. \& Minkov, M. (2010). Cultures and Organizations: Software of the Mind (Rev. 3rd ed.). New York: McGraw-Hill.

Homburg, C., Fürst, A., \& Koschate, N. (2010). On the Importance of Complaint Handling Design: A Multi-Level Analysis of the Impact in Specific Complaint Situations. Journal of the Academy of Marketing Science, 38(3), 265-287

Homburg, C., \& Giering, A. (2001). Personal characteristics as moderators of the relationship between customer satisfaction and loyalty — an empirical analysis. Psychology \& Marketing, 18(1), 43-66.

Homburg, C., Koschate, N., \& Hoyer, W. D. (2005), Do Satisfied Customers Really Pay More? A Study of the Relationship Between Customer Satisfaction and Willingness to Pay, Journal of Marketing, 69 (4), 84-97.

Hwanga, Y. and Lee, C. K (2012), Investigating the moderating role of uncertainty avoidance cultural values on multidimensional online trust, Information \& Management, 49 (3-4) pp. 171176

Insurance Association of Turkey (2016), available at https://www.tsb.org.tr/aboutus.aspx?pageID=919, accessed on $15^{\text {th }}$ September 2018.

Insurance Association of Turkey (2017). Insurance Statistics. http://www.tsb.org.tr/resmiistatistikler.aspx?pageID=909 (accessed July 2018).

Jain, A. K; Malhotra, N. K. and Guan, C. (2012), Positive and Negative Affectivity as Mediators of Volunteerism and Service-Oriented Citizenship Behavior and Customer Loyalty, Psychology and Marketing, 29 (12), pp. 1004-1017.

Johnson, D., \& Grayson, K. (2005). Cognitive and affective trust in service relationships. Journal of Business Research, 58(4), pp. 500-507.

Johnson, D. M., and Seigyoung Auh (1998), ,Customer Satisfaction, Loyalty, and the Trust Environment", in NA - Advances in Consumer Research, 25 (1), pp. 15-20.

Johnson, D. M., Gustafsson, A., Andreassen, T. W., Lervik, L., \& Cha, J. (2001). The evolution and future of national customer satisfaction index models. Journal of economic Psychology, 22(2), pp. 217-245.

Jones, M. A., \& Suh, J. (2000). Transaction-specific satisfaction and overall satisfaction: an empirical analysis. Journal of Services Marketing, 14(2), pp 147-159.

Keh, H. T., \& Xie, Y. (2009). Corporate reputation and customer behavioral intentions: The roles of trust, identification and commitment. Industrial Marketing Management, 38(7), pp 732-742. 
Kim, D. J., Ferrin, D. L., \& Rao, H. R. (2009). Trust and satisfaction, two stepping stones for successful E-commerce relationships: A longitudinal exploration. Information Systems Research, 20(2), pp 237-257.

Kırkbeşoğlu, E. (2012). "Strategic reactions of organizations to legal environment: a typology for industries in the process of institutionalization". International Journal of Business, Humanities and Technology. 2(3), pp. 68 - 72. 2012.

Kharouf, H., Lund, J. D., Sekhon, H. (2014) "Building trust by signaling trustworthiness in service retail", Journal of Services Marketing, 28(5), pp 361-373,

Knox, S., \& Walker, D. (2001). Measuring and managing brand loyalty. Journal of Strategic Marketing, 9(2), 111-128.

Kumar, V., \& Shah, D. (2004). Building and sustaining profitable customer loyalty for the $21 \mathrm{st}$ century. Journal of retailing, 80(4), pp 317-329.

Lam, S. Y., Shankar, V., Erramilli, M. K., \& Murthy, B. (2004). Customer value, satisfaction, loyalty, and switching costs: an illustration from a business-to-business service context. Journal of the Academy of Marketing Science, 32(3), pp 293-311.

Lambe, C.J., Wittmann, M., Sekman, R.E., 2001. Social exchange theory and research on business-to-business relational exchange. Journal of Business to Business Marketing, 8 (3), pp $1-36$.

Lawler, E. J. (2001). An Affect Theory of Social Exchange1. American Journal of Sociology, 107(2), pp 321-352.

Miceli, R., Sotgiu, I. \& Settanni, M. (2008). Disaster preparedness and perception of flood risk: A study in an alpine valley in Italy. Journal of Environmental Psychology, 28(2), pp.164--173.

McLeary, N. C., and Cruise, A. P. (2015) "A context-specific model of organizational trust: An examination of cognitive and socio-affective trust determinants in unique cultural settings", Cross Cultural Management. 22 (2), pp 297-320

McKnight, D.H. and Chervany, N.L. (2002) What Trust Means in E-Commerce Customer Relationships: An Interdisciplinary Conceptual Typology. International Journal of Electronic Commerce, 6 (2), 35-60.

McKnight, D.H and Cummings, L.L and Chervany, L.N (1998), Initial Trust formation in New organisational relationships, Academy Management Review, 22(3), pp 473-490.

Meyer-Waarden, L (2013) "The impact of reward personalisation on frequent flyer programmes ' perceived value and loyalty", Journal of Services Marketing, 27 (3), pp.183-194.

Moody, D. G; Galletta, F. D; Lowry, B. P (2014), when trust and distrust collide online: The engenderment and role of consumer ambivalence in online consumer behaviour. Electronic Commerce Research and Applications, 13 (4), pp 266-282. 
Moorman, C., Zaltman, G., \& Deshpande, R. (1992). Relationships between providers and users of market research: the dynamics of trust within and between organizations, Journal of marketing research, 29(3), pp. 314-328.

Moorman, C., Deshpande, R., Zaltman, G., 1993. Factors affecting trust in market research relationships, Journal of Marketing 57 (1), 81-101.

Morgan, R. M., \& Hunt, S. D. (1994). The commitment-trust theory of relationship marketing. The Journal of Marketing, 58 (3), 20-38.

Mouzas, S., Henneberg, S., \& Naudé, P. (2007). Trust and reliance in business relationships. European Journal of Marketing, 41(9/10), 1016-1032.

Nagengast, L., Evanschitzky, H; Blut, M., Rudolph, T. (2014). New Insights in the Moderating Effect of Switching Costs on the Satisfaction-Repurchase Behavior Link. Journal of Retailing, 90(3), pp. 408-427

Naskrent, J., \& Siebelt, P. (2011). The influence of commitment, trust, satisfaction, and involvement on donor retention. Voluntas, Vol 22(4), 757-778.

Nichonson, C.Y., Compeau, L.D. and Sethi, R. (2001). The role of interpersonal liking in building trust in long-term channel relationships. Journal of the Academy of Marketing Science, 29(1), pp. 3-15.

Ndubisi, O. N., (2004). Understanding the salience of cultural dimensions on relationship marketing, it's underpinnings and aftermaths", Cross Cultural Management: An International Journal, 11(3), pp.70-89

Ndubisi, N. O. (2011). Conflict handling, trust and commitment in outsourcing relationship: A Chinese and Indian study. Industrial Marketing Management, 40(1), pp 109-117.

Oltedal,S. Moen, B., Klempe, H.\& Rundmo, T. (2004). Explaining Risk Perception: An evaluation of cultural theory, Trondheim.

Ojeme, M., Robson, A., Coates, N. (2018) Investigating the Nigerian small and medium enterprises (SMEs)-banking long-term relationship building, International Journal of Bank Marketing, 36(1), pp.89-110.

Ojeme, M (2017) Assessing the Impact of Relationship Length in the SMEs and Bank Association. International Journal of Marketing Studies, 9 (5), 17-27.

Oliver (1997) Satisfaction: a behavioral perspective on the consumer. US: Mcgraw

Oliva, T. A., Oliver, R. L., \& MacMillan, I. C. (1992). A catastrophe model for developing service satisfaction strategies. The Journal of Marketing, 56 (7), pp. 83-95.

Oliver, R. L. (1999). Whence consumer loyalty? The Journal of Marketing, 63 (4), pp. 33-44.

Oliver, R. L. (1980). A cognitive model of the antecedents and consequences of satisfaction decisions. Journal of marketing research, 17 (4), pp. 460-469. 
Oliver, C. (1991). Strategic Responses to Institutional Processes, The Academy of Management Review, 16 (1:), pp: 145-179.

Olsen, S. O. (2007). Repurchase loyalty: the role of involvement and satisfaction. Psychology \& Marketing, 24(4), pp. 315-341.

Organisation for Economic Co-Operation and Development Statistics (2016), available at https://stats.oecd.org/ accessed on $15^{\text {th }}$ September 2018.

Pick, D. and Eisend, M. (2016) Customer Responses to Switching Costs: A Meta-Analytic Investigation of the Moderating Influence of Culture', Journal of International Marketing, 24(4), pp. 39-60.

Picon, A., Castro, I., \& Roldan, J. L. (2014). The relationship between satisfaction and loyalty: A mediator analysis. Journal of Business Research, 67(5), pp 746-751.

Podsakoff, P. M. et al. (2003) Common method biases in behavioral research: A critical review of the literature and recommended remedies', Journal of Applied Psychology, 88(5), pp. 879903.

Pura, M. (2005) "Linking perceived value and loyalty in location-based mobile services", Managing Service Quality: An International Journal, 15 (6), pp.509-538,

Qu, G. W and Yang, Y. Z (2015), The effect of uncertainty avoidance and social trust on supply chain collaboration, Journal of Business Research, 68 (5), pp. 911-918.

Rauyruen, P., \& Miller, K. E. (2007). Relationship quality as a predictor of B2B customer loyalty. Journal of Business Research, 60(1), pp. 21-31.

Rauyruen, P., Miller, K. E., \& Groth, M. (2009). B2B services: linking service loyalty and brand equity. Journal of Services Marketing, 23(3), pp. 175-186.

Reimann, M., Lünemann, F. U., and Chase., B. R (2008). Uncertainty Avoidance as a Moderator of the Relationship between Perceived Service Quality and Customer Satisfaction, Journal of Service Research, 11(1), pp. 63-73.

Reichheld, F., \& Teal, T. (1996). The Loyalty Effect. Boston: Harvard Business School Press.

Rejda, G.E. (2005). Principles of Risk Management and Insurance, 9th edition. Pearson.

Reichheld FF, Sasser Jr. WE. Zero defections: Quality comes to services. Harvard Business Review. 1990; 68(5), pp105-111.

Rios, F., Rodriguez-Priego, N. \& Georgantzis, N. (2014). Risk Perception and the Commitment to Reduce Global Climate Change in Spain, Revista Internacional Desociologia, 72(1), pp. 173-200. 
Robson, A, Ojeme, M and Coates, N (2016) The SMEs' perspective of trust in a B2B relationship. Journal of Financial Services Marketing, 21 (2). pp. 103-112.

Roman, S. (2003). The impact of ethical sales behaviour on customer satisfaction, trust and loyalty to the company: An empirical study in the financial services industry. Journal of marketing management, 19(9-10), 915-939.

Sampaio, H.C, Ladeira, J.W., Santini, O.F. (2017) "Apps for mobile banking and customer satisfaction: a cross-cultural study", International Journal of Bank Marketing, 35(7),pp.11331153.

Schul, Yaacov, Mayo, R and Burnstein, E (2008). The Value of Distrust, Journal of Experimental Social Psychology, 44 (5), pp. 1293-1302.

Schul, Y., Mayo, R., \& Burnstein, E. (2004). Encoding under trust and distrust: The spontaneous activation of incongruent cognitions. Journal of Personality and Social Psychology, 86, 668-679.

Schul, Y., Burnstein, E., \& Bardi, A. (1996). Dealing with deceptions that are difficult to detect: Encoding and judgment as a function of preparing to receive invalid information. Journal of Experimental Social Psychology, 32, 228-253.

Sekhon, H., Roy, S., Shergill, G., P ritchard, A. (2013) "Modelling trust in service relationships: a transnational perspective", Journal of Services Marketing, 27(1), 76-86.

Şener, T. (2016). Sigortacılık sektöründe hizmet kalitesinin ölçülmesi ve algılanan hizmet kalitesi ile beklenen hizmet kalitesi arasındaki ilişkinin incelenmesi: Antalya ili örneği. The Journal of Academic Social Science Studies, 2016(50), 497-510.

Setó-Pamies, Dolors (2012). Customer loyalty to service providers: examining the role of service quality, customer satisfaction and trust Total Quality Management \& Business Excellence. Vol. 23 (11/12), p1257-1271.

Shankar, V., Smith, A. K., \& Rangaswamy, A. (2003). Customer satisfaction and loyalty in online and offline environments. International Journal of Research in Marketing, 20(2), pp. 153175.

Simpson, B., Harrell, A., \& Willer, R. (2013). Hidden paths from morality to cooperation: Moral judgments promote trust and trustworthiness. Social Forces, 91(4), pp. 1529-1548.

Sjoberg, L., Moen, B. \& Rundmo, T. (2004). Explaining risk perception. An evaluation of the psychometric paradigm in risk perception research. Trondheim.

Slovic, P. (1987). Perception of Risk. Science, 236(4799), pp. 280-285

Slovic, P. \& Gregory, R. (1999). Risk analysis, decision analysis, and the social context for risk decision making. Springer, pp. 353-365.

Storrud-Barnes, F S., Reed, R., and Jessup, M. L. (2010) "Uncertainty, risk preference, and newventure strategies", Journal of Strategy and Management, 3(3), pp.273-284. 
Singh, J., \& Sirdeshmukh, D. (2000). Agency and trust mechanisms in consumer satisfaction and loyalty judgments. Journal of the Academy of Marketing Science, 28(1), 150-167.

Sirdeshmukh, D., Singh, J., \& Sabol, B. (2002). Consumer trust, value, and loyalty in relational exchanges. Journal of Marketing, 66(1), 15-37.

Toma, M, Chiriţă, Mioara and Şarpe, D (2012), Risk and Uncertainty, Procedia Economics and Finance, 3, pp. 975-980.

Tourangeau, R., Rips, L. J., \& Rasinski, K. (2000). The psychology of survey response.

Cambridge, England: Cambridge University Press

Turkish Statistical Institute (2000). Employed population by economic activity and sex, available http://www.tuik.gov.tr/PreIstatistikTablo.do?istab_id=236, accessed on $3^{\text {rd }}$ April, 2017.

Veloutsou, C., Gilbert, G. R., Moutinho, L. A., \& Goode, M. M. (2005). Measuring transactionspecific satisfaction in services: are the measures transferable across cultures? European Journal of Marketing, 39(5/6), 606-628.

Wildavsky, A. \& Dake, K. (1990). Theories of risk perception: Who fears what and why? Daedalus, 119, pp. 41-60.

Wallace, D. W., Giese, J. L., \& Johnson, J. L. (2004). Customer retailer loyalty in the context of multiple channel strategies. Journal of retailing, 80(4), 249-263.

Yiğiter, Ş. Y. (2011). İçsel performans göstergeleri ve müşteri memnuniyeti ilişkisi. Akademik Bakış Dergisi, 2011(23), 1-17.

Yi, Y. and Nataraajan, R. (2018), Customer Satisfaction in Asia, Pschology and Markeitng, 35 (6), pp 383-487.

Zaheer, S., \& Zaheer, A. (2006). Trust across borders. Journal of International Business Studies, 37(1), 21-29.

Zeithaml, V. A., Berry, L. L., \& Parasuraman, A. (1996). The behavioral consequences of service quality. Journal of Marketing, 60(2), 31.

\section{Acknowledgments}

We are grateful to Sukran Gokdogan and Hakan Gokdogan for supporting us in reaching out to participants for data collection and sharing their first-hand experience in optimising our measurement items.

\section{Adapted Measurement Items and References} Uncertainty Avoidance (UA)

1) It is important for my insurance company to have instructions explained in detail (Sampaio et al., 2017). 
2) Government rules and regulations are important because they inform me of the appropriate automobile insurance policy to buy (Hwang and Lee, 2012).

3 ) It is important to buy the suitable insurance policy for my circumstance.

4) Comprehensive insurance policy is helpful (Sampaio et al., 2017).

5) Clear instructions from my insurance company are important (Sampaio et al., 2017).

6) Insurance companies should make sure to inform customers about their rights according to the government rules and regulations (Sampaio et al., 2017).

Situational Abnormality (SA)

1) I do not feel good about the automobile insurance policy in Turkey (Moody, Galleta and Lowry, 2014).

2) I would feel uncomfortable purchasing the insurance policy offered (Moody, Galleta and Lowry, 2014).

3) I do not believe that the automobile policy provided to me is correct (Moody, Galleta and Lowry, 2014).

4) The buying process of my automobile policy included things I did not expect (Moody, Galleta and Lowry, 2014).

5) The automobile insurance policy offered is not complete (Moody, Galleta and Lowry, 2014).

Satisfaction

1) In general, I am very satisfied with my insurance company (Lam et al. 2004).

2) Overall, it has been good to have my car insured with my insurance company(Lam et al. 2004)..

3) Overall, the policy of my insurance company meets up to my expectations (Lam et al. 2004)..

4) Overall, my insurance company treats me very fairly (Lam et al. 2004)..

Trust

1) Promises made by my insurance company are reliable (Coote, Forrest, and Tam (2003).

2) My insurance company treats me in an honest way about my policy enquiry (Ball, Coelho and Machas (2004).

3) In times of uncertainty and vulnerability, my insurance company has my best interests in mind (Cater and Cater (2010).

4) I have great confidence in my insurance company (Coote, Forrest, and Tam (2003).

5) My insurance company is genuinely concerned about my driving safety (Ball, Coelho and Machas (2004).

Loyalty

1) I will spend more money to buy additional insurance policy (Keh and Xie, 2009).

2) I will recommend my insurance broker to other people that seek my advice (Fullerton, 2005).

3) I say positive things to other people about my insurance broker (Fullerton, 2005).

4) I will continue to buy insurance policy from my broker in the next few years (Keh and Xie, 2009). 